\title{
Experimental Study on the Electrochemical Anti-Corrosion Properties of Steel Structures Applying the Arc Thermal Metal Spraying Method
}

\author{
Hong-Bok Choe ${ }^{1}$, Han-Seung Lee ${ }^{1, *}$ and Jun-Ho Shin ${ }^{2}$
}

1 Department of Architectural Engineering, Hanyang University, 1271 Sa 3-dong, Sangrok-gu, Ansan 426-791, Korea; E-Mail: hongbokchoe@gmail.com

2 Department of Architectural Engineering, Gachon University, 1342 Seongnamdaero, Sujeong-gu, Seongnam-si, Gyeonggi-do 461-701, Korea; E-Mail: jhshin0720@ gachon.ac.kr

* Author to whom correspondence should be addressed; E-Mail: ercleehs@ hanyang.ac.kr; Tel.: +82-31-400-5181; Fax: +82-31-436-8169.

External Editor: Daolun Chen

Received: 17 August 2014; in revised form: 12 November 2014 / Accepted: 25 November 2014 / Published: 3 December 2014

\begin{abstract}
The arc thermal metal spraying method (ATMSM) provides proven long-term protective coating systems using zinc, aluminum and their alloys for steel work in a marine environment. This paper focuses on studying experimentally the anti-corrosion criteria of ATMSM on steel specimens. The effects of the types of spraying metal and the presence or absence of sealing treatment from the thermal spraying of film on the anti-corrosion performance of TMSM were quantitatively evaluated by electrochemical techniques. The results showed that ATMSM represented a sufficient corrosion resistance with the driving force based on the potential difference of more than approximately $0.60 \mathrm{~V}$ between the thermal spraying layer and the base substrate steel. Furthermore, it was found that the sealing treatment of specimens had suppressed the dissolution of metals, increased the corrosion potential, decreased the corrosion current density and increased the polarization resistance. Metal alloy $\mathrm{Al}-\mathrm{Mg}(95 \%: 5 \%)$ by mass with epoxy sealing coating led to the most successful anti-corrosion performance in these electrochemical experiments.
\end{abstract}

Keywords: arc thermal metal spray; electrochemical technique; anti-corrosion; steel structures 


\section{Introduction}

A hot dip galvanizing (HDG) method using zinc ( $\mathrm{Zn}$ ) and a heavy-duty coating method that applies the spraying of zinc-rich paint on primer and that combines epoxy resin and fluoride resin have been largely favored [1-3]. However, these methods showed several problems. In particular, the heavy-duty coating method requires re-coating within 10-15 years, and that significantly increases the maintenance costs in semi-permanent steel structures; besides, it may include certain toxic elements in the applied coating [4]. Furthermore, the hot dip galvanizing method represents weak points, such as the size limitations of structural members, the thermal deformation of base materials and difficulties in welding after applying the coating in high-strength joint parts [5]. The hot dip galvanizing method generated detached coating layers with time and showed deterioration in the external appearance in outdoor applications due to partially contaminated black areas and chloride carbonic zinc [6].

In recent years, a thermal metal spraying method that produces an anti-corrosion layer on the surface of steel materials by melting $\mathrm{Zn}$ or $\mathrm{Al}$, which has a relation to the sacrificial anode, using gas or electricity instead of the conventional corrosion resistance method, is attracting many researchers presently [7-9]. Thus, it is of great importance to select an appropriate thermal metal spraying method depending on the environmental conditions, as the anti-corrosion performance of the arc thermal metal spraying method (ATMSM) is highly influenced by the types of metals used [10,11]. In addition, the thermal spraying layer has a porous structure, and the characteristics of the anti-corrosion criteria vary with the process of applying the sealing coating that fills the pores [12]. Meanwhile, a quantitative study of this method with electrochemical experiments is needed, as conventional experiments, such as CASS (Copper ions accelerated salt spray) testing and salt spraying testing, have a qualitative limitation in the evaluation of the durability lifetime in ATMSM [13-17].

Furthermore, sacrificial anode metals, such as tin ( $\mathrm{Sn})$, magnesium ( $\mathrm{Mg}$ ) and indium (In), which have a better quality of corrosion resistance than zinc ( $\mathrm{Zn}$ ) or aluminum (Al), have been under extensive research study [18]. However, it seems that there are very few works that quantitatively evaluate the electrochemical performance of ATMSM using these metals [19-21].

The objective of the study is to quantitatively evaluate by the electrochemical technique the influence of the metal wire type and the presence of the epoxy sealing coating treatment of the sprayed layer on the anti-corrosion performance of ATMSM.

\section{Experiments}

Table 1 shows the specimens that were used for the electrochemical experiments, which were conducted with the type of sprayed metal and the presence or absence of epoxy sealing coating. Pure zinc with a diameter of $1.6 \mathrm{~mm}$, pure aluminum, $\mathrm{Zn}-\mathrm{Sn}(65 \%: 35 \%$ by mass (alloy)) and $\mathrm{Al}-\mathrm{Mg}$ (95\%:5\% by mass (alloy)) were used as thermal spraying metals. Non-painted steel plates and hot dip galvanized steel plates produced at the factory were used for comparison. After blasting with grit, a thermal spray coating layer of a thickness up to $100 \mu \mathrm{m}$ on the surface of steel plates is produced by using an arc thermal spraying gun, as shown in Figure 1 [7-9]. The $\mathrm{Zn}-\mathrm{Al}$ thermal metal spraying method is a method that produces a corrosion resistance layer on the surface of steel materials using compressed air by melting metals, such as $\mathrm{Zn}$ and $\mathrm{Al}$, with electric arcs. Figure 1 demonstrates an arc 
sprayer used in a $\mathrm{Zn}-\mathrm{Al}$ thermal metal spraying method. The metal spraying discharges the metal melted at an arc point through a circular slit, and that can be introduced into an air stream in which it can be diffused and cooled. Then, the diffused metal generates a layer on the surface of steel by avoiding collisions and forms a porous metal spraying layer according to the accumulation and solidification of such layers. Test specimens ( $\mathrm{Zn} \mathrm{73 \% :Al} \mathrm{27 \% )} \mathrm{sealed} \mathrm{with} \mathrm{epoxy} \mathrm{coating} \mathrm{after} \mathrm{the}$ formation of the thermal spray coating layer were also prepared.

Table 1. Specimens for the electrochemical experiments.

\begin{tabular}{|c|c|c|c|c|c|}
\hline No. & $\begin{array}{l}\text { Specimen } \\
\text { Name }\end{array}$ & $\begin{array}{c}\text { Specimens for } \\
\text { Electrochemical Test }\end{array}$ & $\begin{array}{l}\text { Epoxy Sealing } \\
\text { Coating }\end{array}$ & $\begin{array}{c}\text { Types of Spraying } \\
\text { Metal }\end{array}$ & $\begin{array}{l}\text { Anti-Corrosion } \\
\text { Method }\end{array}$ \\
\hline 1 & NP & Non-painted specimen & No & - & - \\
\hline 2 & HDG & $\begin{array}{l}\text { Hot dip galvanizing (zinc) } \\
\qquad 400 \mathrm{~g} / \mathrm{m}^{2}\end{array}$ & No & - & Plating \\
\hline 3 & Z100-NS & $\mathrm{Zn}$ (mass $100 \%)$ & No & $\mathrm{Zn}-\mathrm{Zn}$ & \multirow{9}{*}{$\begin{array}{c}\text { Arc thermal metal } \\
\text { spray }\end{array}$} \\
\hline 4 & Z100-S & $\mathrm{Zn}$ (mass $100 \%)$ & Yes & $\mathrm{Zn}-\mathrm{Zn}$ & \\
\hline 5 & A100-NS & $\mathrm{Al}$ (mass $100 \%$ ) & No & $\mathrm{Al}-\mathrm{Al}$ & \\
\hline 6 & A100-S & $\mathrm{Al}$ (mass $100 \%$ ) & Yes & $\mathrm{Al}-\mathrm{Al}$ & \\
\hline 7 & Z73-A27-NS & $\mathrm{Zn}-\mathrm{Al}$ (mass 27\%) & No & $\mathrm{Zn}-\mathrm{Al}$ & \\
\hline 8 & Z73-A27-S & $\mathrm{Zn}-\mathrm{Al}$ (mass 27\%) & Yes & $\mathrm{Zn}-\mathrm{Al}$ & \\
\hline 9 & Z65-S35-NS & $\mathrm{Zn}-\mathrm{Sn}$ (mass $35 \%$ ) & No & $\mathrm{Zn} \cdot \mathrm{Sn}-\mathrm{Zn} \cdot \mathrm{Sn}$ & \\
\hline 10 & Z65-S35-S & $\mathrm{Zn}-\mathrm{Sn}$ (mass $35 \%$ ) & Yes & $\mathrm{Zn} \cdot \mathrm{Sn}-\mathrm{Zn} \cdot \mathrm{Sn}$ & \\
\hline 11 & A95-M5-NS & $\mathrm{Al}-\mathrm{Mg}$ (mass $5 \%$ ) & No & $\mathrm{Al} \cdot \mathrm{Mg}-\mathrm{Al} \cdot \mathrm{Mg}$ & \\
\hline 12 & A95-M5-S & $\mathrm{Al}-\mathrm{Mg}$ (mass 5\%) & Yes & $\mathrm{Al} \cdot \mathrm{Mg}-\mathrm{Al} \cdot \mathrm{Mg}$ & - \\
\hline
\end{tabular}

Common items

Steel plate: SS41, $15 \mathrm{~mm} \times 15 \mathrm{~mm} \times 1.6 \mathrm{~mm}$ thickness; experimental area: $0.78 \mathrm{~cm}^{2}$ Steel surface treatment: grit blast

Figure 1. Arc thermal metal spraying method.
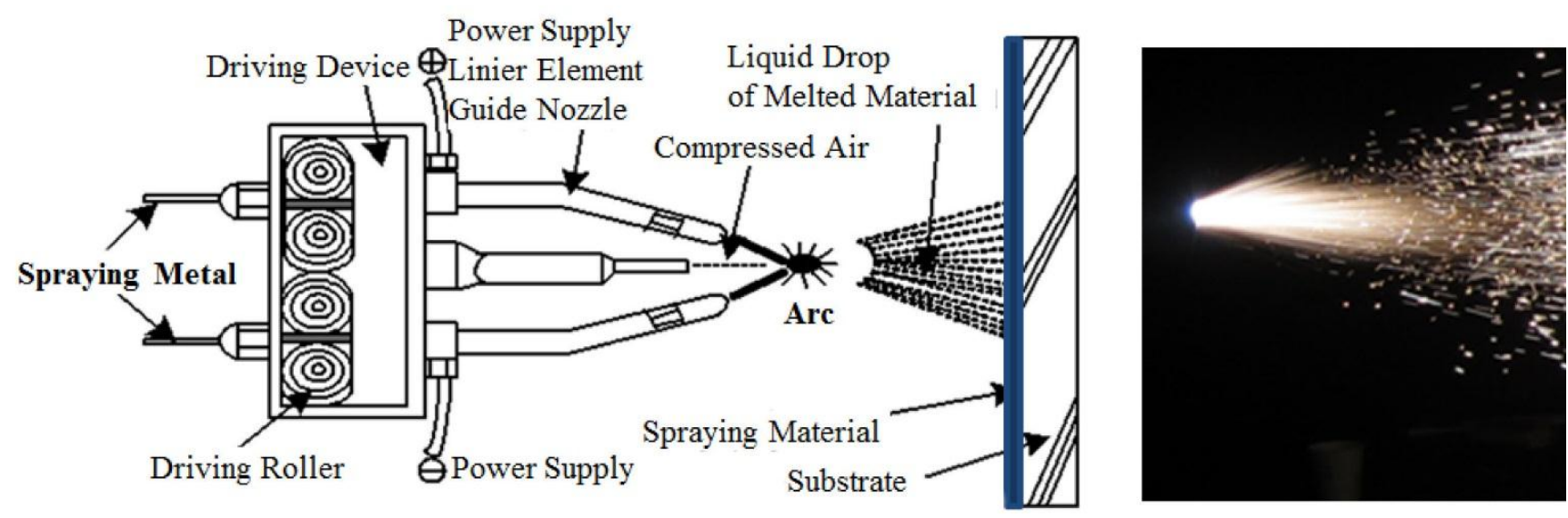

A $15 \mathrm{~mm} \times 15 \mathrm{~mm}$ specimen was connected to electric wires in which all spaces, except for $0.78 \mathrm{~cm}^{2}$, were sealed to prevent electric contacts. Corrosion potential and polarization resistance were measured through the exposed section of $0.78 \mathrm{~cm}^{2}$. 
An electrochemical system with three electrodes, where the specimen was configured as a working electrode (WE), graphite was configured as a counter electrode (CE), and a silver-silver electrode $(\mathrm{Ag} / \mathrm{AgCl})$ was configured as a reference electrode, was used in this study. Figure 2 shows the setup for the electrochemical experiment. In addition, a VersaSTAT (Princeton Applied Research, Oak Ridge, TN, USA) was used to analyze the results of these experiments.

Changes in potential and currents were measured with a $1.0-\mathrm{mV} / \mathrm{s}$ projection speed in the range of $-0.4-+0.8 \mathrm{mV}$ based on the corrosion potential. Then, the polarization resistance was observed by calculating the obtained potential. The solution used in this experiment was a $3.5 \mathrm{wt} \% \mathrm{NaCl}$ solution at $25{ }^{\circ} \mathrm{C}$.

Figure 2. Schematic diagram for test setup. WE: working electrode; CE: counter electrode.

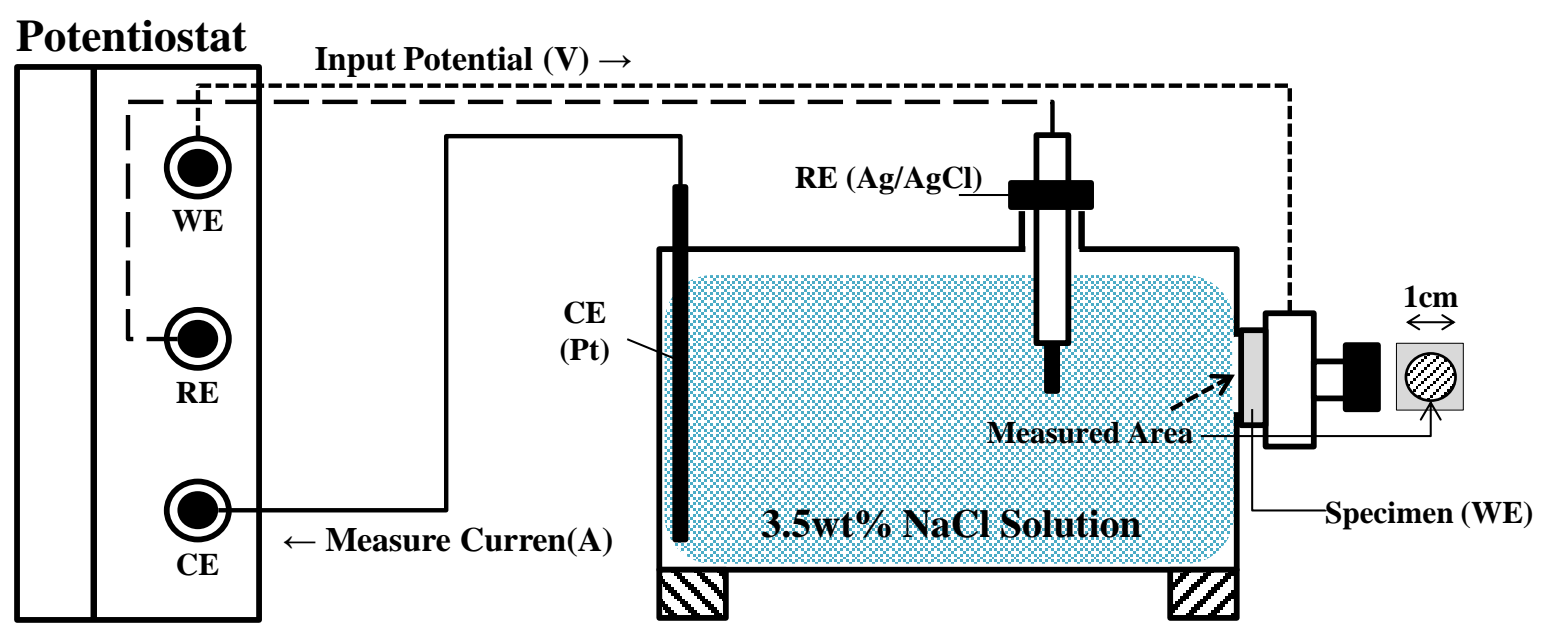

Table 2 shows sectional images produced using an SEM (scanning electron microscopy). In the case of the hot dip zinc galvanizing method, it shows a very dense, uniform and high adhesive layer that enables the specimen to have very good corrosion resistance in steel structures based on the sacrificial anode of $\mathrm{Zn}$.

In the case of the specimens that were coated using pure Zn (No. 3) and Al (No. 4) by ATMSM, it appears that there is a rough surface accompanying many open holes. There are also some pores and micro-cracks in the image morphology, but these pores and cracks were not connected with each other nor traversing the coating from the coating surface to the steel substrate.

For the specimen with $\mathrm{Zn}-\mathrm{Al}$ thermal metal spray (No. 5), the melted $\mathrm{Zn}$ (dark color) and $\mathrm{Al}$ (bright color) accumulated and formed a dense pseudo-alloy coating on the surface of the steel plates. A similar observation can be seen in specimen No. 6, too. As for $\mathrm{Zn}-\mathrm{Sn}$ (65\%:35\%) in the mass specimen, there is rough surface accompanying many open holes. There are also many pores and micro-cracks in the image morphology. Specimen No. 8 shows a clear rough surface accompanying open holes, and also, there are some pores with a relatively large size.

From these SEM images, one can see that, based on the principal of a sacrificial anode, specimens coated with $\mathrm{Zn}, \mathrm{Al}, \mathrm{Zn}-\mathrm{Al}, \mathrm{Zn}-\mathrm{Sn}$ and $\mathrm{Al}-\mathrm{Mg}$ by ATMSM have a relatively high potential to resist corrosion. 
Table 2. SEM (scanning electron microscopy) images for each corrosion resistance method.

No. Specimen Name $\quad$ SEM Image


Table 2. Cont.

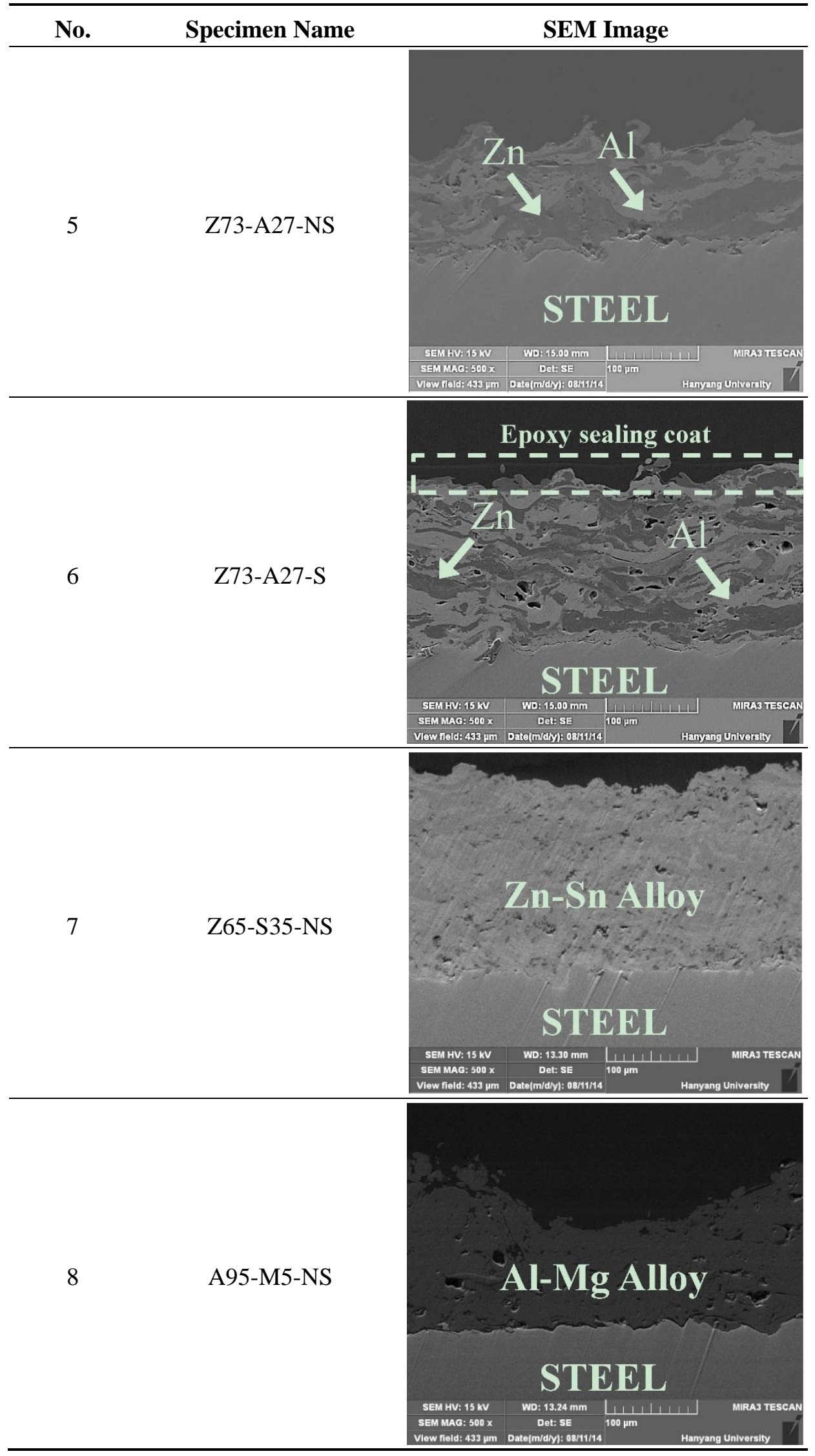




\section{Discussion}

\subsection{Experimental Results}

Table 3 shows the results of the electrochemical tests. The corrosion potential of the non-painted specimen was $-0.61 \mathrm{~V}$ and the other specimens showed more negative corrosion potential. Thus, the sacrificial anodic reaction of the sprayed metal made the steel plate effectively anti-corroded in HDG and metal spray specimens. It is also seen in this table that the comparison of the corrosion potential values of all specimens in relation to HDG suggests that epoxy sealing coating contributes dramatically to the corrosion resistance performance of these specimens coated with ATMSM.

Table 3. Electrochemical test results.

\begin{tabular}{ccccc}
\hline No. & $\begin{array}{c}\text { Specimen } \\
\text { Name }\end{array}$ & $\begin{array}{c}\text { Open Circuit Potential } \\
(\mathbf{V})\end{array}$ & $\begin{array}{c}\text { Corrosion Potential } \\
(\mathbf{V})\end{array}$ & $\begin{array}{c}\text { Relative Corrosion Rate } \\
(\text { HDG }=\mathbf{1})\end{array}$ \\
\hline 1 & NP & -0.55 & -0.61 & 0.30 \\
2 & HDG & -0.92 & -0.91 & 1.00 \\
3 & Z100-NS & -1.03 & -1.25 & 2.27 \\
4 & Z100-S & -0.98 & -0.96 & 0.98 \\
5 & A100-NS & -0.99 & -1.06 & 0.34 \\
6 & A100-S & -0.10 & -1.02 & 0.01 \\
7 & Z73-A27-NS & -1.05 & -1.23 & 0.19 \\
8 & Z73-A27-S & -0.98 & -0.97 & 0.02 \\
9 & Z65-S35-NS & -1.03 & -1.30 & 0.66 \\
10 & Z65-S35-S & -0.97 & -0.98 & 0.16 \\
11 & A95-M5-NS & -0.86 & -1.07 & 0.18 \\
12 & A95-M5-S & -0.80 & -0.91 & 0.001 \\
\hline
\end{tabular}

Table 4 shows the corrosion conditions on the surface of the specimens before and after the electrochemical experiment. The surface of the non-painted (NP) specimen was significantly corroded. In particular, the corrosion of the metal spraying layer on the surface of the specimens using $\mathrm{Zn}$ and $\mathrm{Sn}$, the ionization tendencies of which are generally higher than iron, were remarkably observed. The metal spraying layer in specimen Z73-A27-NS, in which the holes were not filled with the epoxy sealing coating, was partially corroded. On the other hand, for the specimens that were coated with epoxy sealing coating, the corrosion of the layer is hardly observed. From these observations, one can see that epoxy sealing coating has an obvious effect on the anti-corrosion performance of thermally-sprayed specimens. 
Table 4. Surface conditions of the specimens before and after carrying out the electrochemical experiment.

\begin{tabular}{|c|c|c|c|c|c|c|c|}
\hline No. & $\begin{array}{c}\text { Specimen } \\
\text { Name } \\
\end{array}$ & Before Exp. & After Exp. & No. & $\begin{array}{c}\text { Specimen } \\
\text { Name }\end{array}$ & Before Exp. & After Exp. \\
\hline 1 & NP & & & 7 & Z73-A27-NS & & \\
\hline 2 & HDG & & & 8 & Z73-A27-S & & \\
\hline 3 & Z100-NS & & & 9 & Z65-S35-NS & & \\
\hline 4 & Z100-S & & & 10 & Z65-S35-S & & \\
\hline 5 & A100-NS & & & 11 & A95-M5-NS & & \\
\hline 6 & A100-S & & & 12 & A95-M5-S & & \\
\hline
\end{tabular}

\subsection{Open Circuit Potential and Corrosion Potential}

Figure 3 illustrates the value of open circuit potentials produced in a very short time in the application of ATMSM. The open circuit potential of the NP specimen was found to be stable at about $-0.55 \mathrm{~V}$ (vs. Ag/AgCl). However, HDG and metal-sprayed specimens showed an open circuit potential between $-0.9 \mathrm{~V}(v s . \mathrm{Ag} / \mathrm{AgCl})$ and $-1.0 \mathrm{~V}(v s . \mathrm{Ag} / \mathrm{AgCl})$, and that value varied depending on the type of sprayed metal. Therefore, ATMSM was found to exhibit a sufficient sacrificial anode effect for the corrosion resistance of steel.

Figure 4 shows the stable corrosion potential $\left(E_{\text {corr }}\right)$ of each tested specimen. The corrosion potential ( $\left.E_{\text {corr }}\right)$ of specimen NP was $-0.606 \mathrm{~V}$ ( $\left.v s . \mathrm{Ag} / \mathrm{AgCl}\right)$. The corrosion potential of metal-sprayed and HDG specimens ranges from -0.9 to $-1.25 \mathrm{~V}$ ( $v s$. $\mathrm{Ag} / \mathrm{AgCl})$, indicating a difference of about $-0.6 \mathrm{~V}$ (vs. $\mathrm{Ag} / \mathrm{AgCl}$ ). Therefore, ATMSM in this experiment is thought to produce an excellent galvanic effect, because the corrosion potential difference of $-0.1 \mathrm{~V}$ ( $v s . \mathrm{Ag} / \mathrm{AgCl}$ ) is generally sufficient. Because $\mathrm{Zn}$ is more vulnerable to corrosion than other metals, specimens coated with $\mathrm{Zn}$ showed a negative potential, which is relatively higher than those of other metals. 
Figure 3. Relationship between open circuit potential and time.

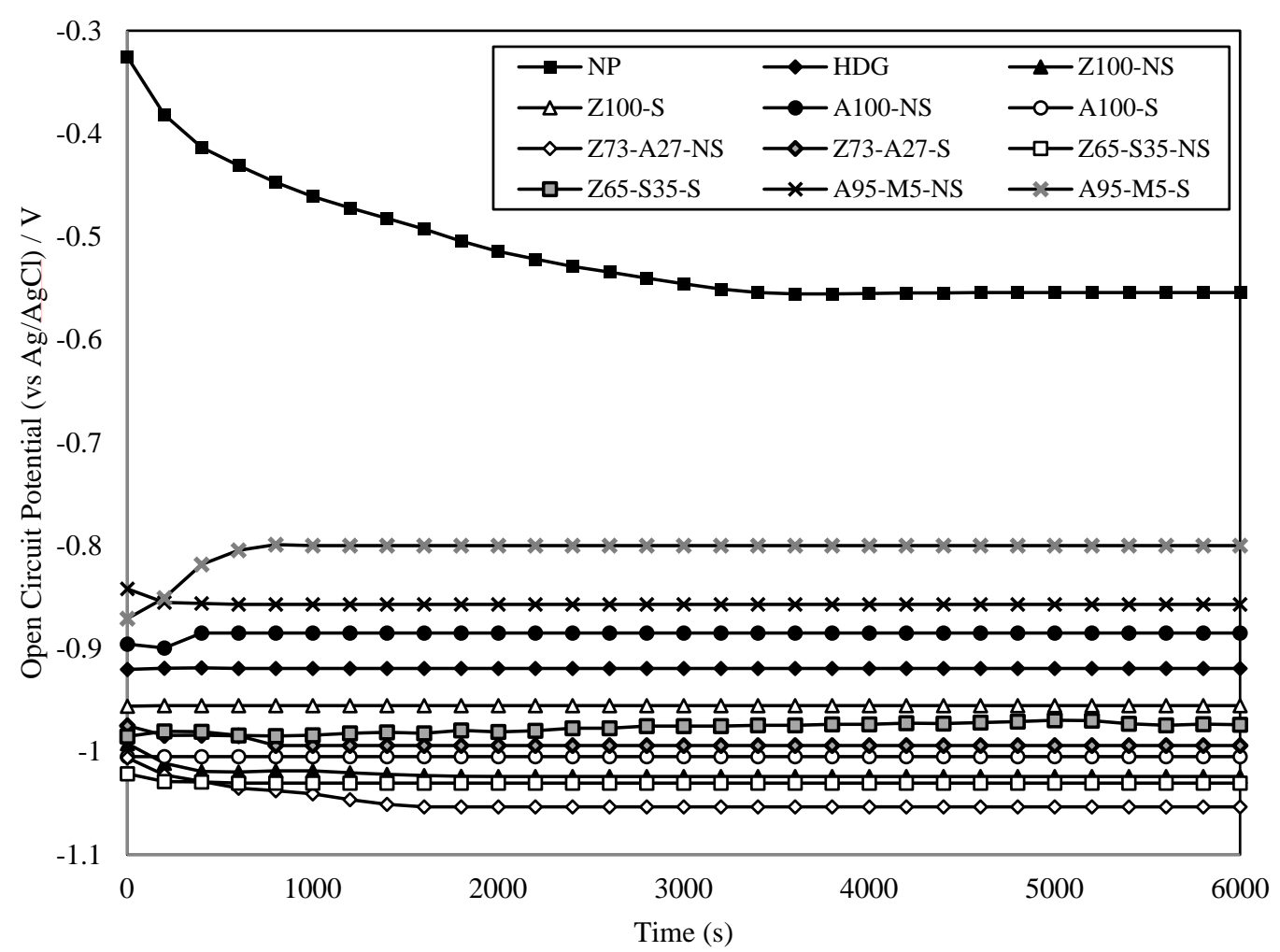

Figure 4. Corrosion potential in each specimen.

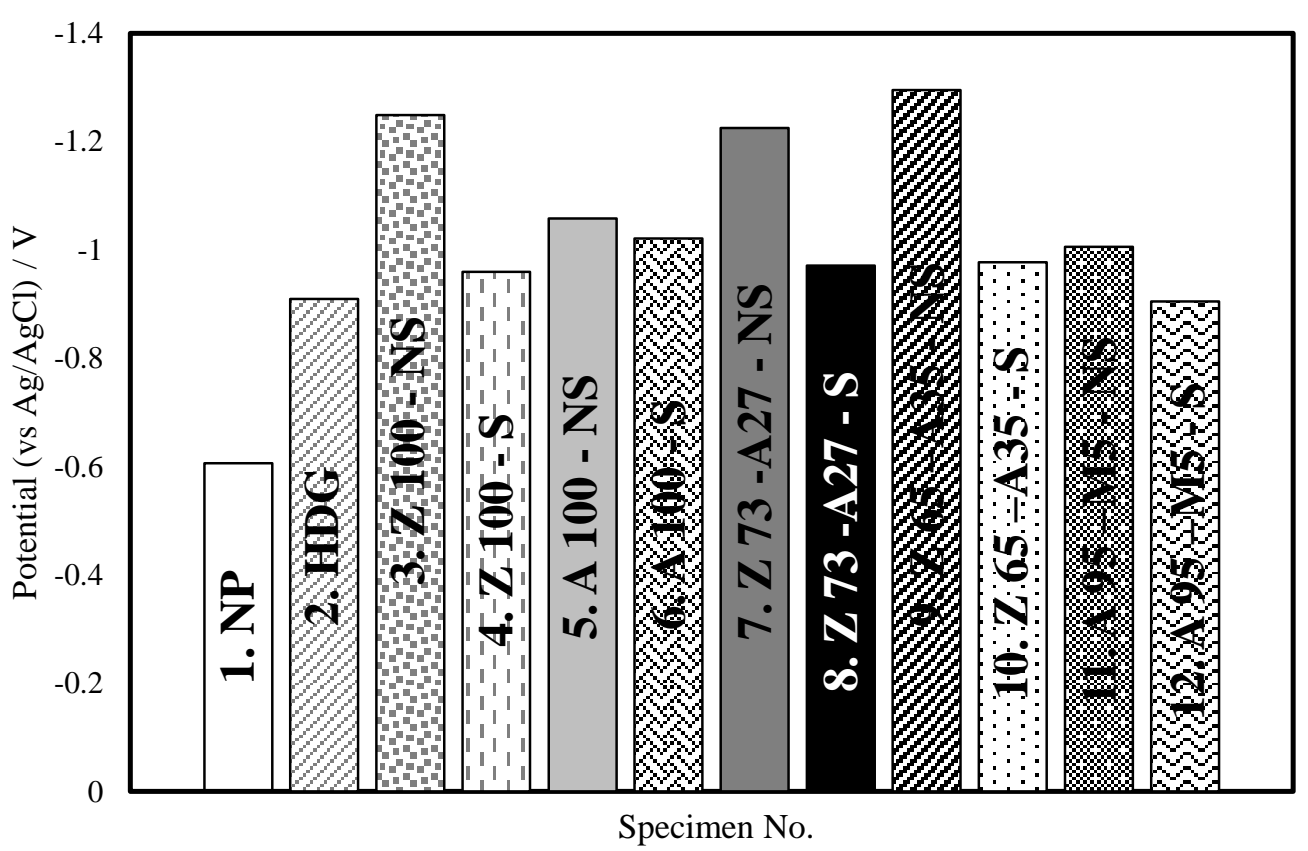

\subsection{Polarization Curve}

Figure 5 shows the polarization curves of specimens in the case of NP, HDG, Z100-NS and Al100-NS. It is clear that there are high potential differences between the coated specimens and non-painted specimen. In the anodic polarization area, the anodic reaction of the HDG specimen using $\mathrm{Zn}$ is as follows: $\mathrm{Zn}+2 \mathrm{Cl}^{-} \rightarrow \mathrm{ZnCl}_{2}+2 \mathrm{e}^{-}$. The melting reaction proceeds rapidly, because the 
polarization curve is close to being horizontal. This is similar to the metal spraying of $\mathrm{Zn}$. The minimum $-1.25 \mathrm{~V}$ indicates that dissolution of $\mathrm{Zn}$ takes place actively and that the galvanic effect is excellent. Stagnation of the current increase near the corrosion current density of $0.0001 \mathrm{~A} \cdot \mathrm{cm}^{-2}$ was partially observed. Because only the top surface of the plates was treated with epoxy sealing coating, corrosion had occurred in some part of the steel surface. On the other hand, specimen Al100-NS showed a corrosion potential of $-1.06 \mathrm{~V}$. The corrosion current density was in a steady state at about $0.0001 \mathrm{~A} \cdot \mathrm{cm}^{-2}$, and it increased rapidly, primarily due to the formation of oxide film $\left(\mathrm{Al}+3 \mathrm{OH}^{-} \rightarrow \mathrm{Al}(\mathrm{OH})_{3}+3 \mathrm{e}^{-}\right)$and of corrosion products $\left(\mathrm{Al}+3 \mathrm{Cl}^{-} \rightarrow \mathrm{AlCl}_{3}+3 \mathrm{e}^{-}\right)$. In the cathodic polarization area, the current in the HDG specimen was in a steady state at about $0.0001 \mathrm{~A} \cdot \mathrm{cm}^{-2}$, which suggests that the surface of the electrode was coated with $\mathrm{Zn}(\mathrm{OH})_{2}$ film at the beginning of polarization. On the other hand, the corrosion current density of specimens Al100-NS and Z100-NS increased steadily, and dissolutions of the metal proceeded smoothly.

Figure 5. Polarization curves of NP, HDG, Z100-NS and Al100-NS specimens.

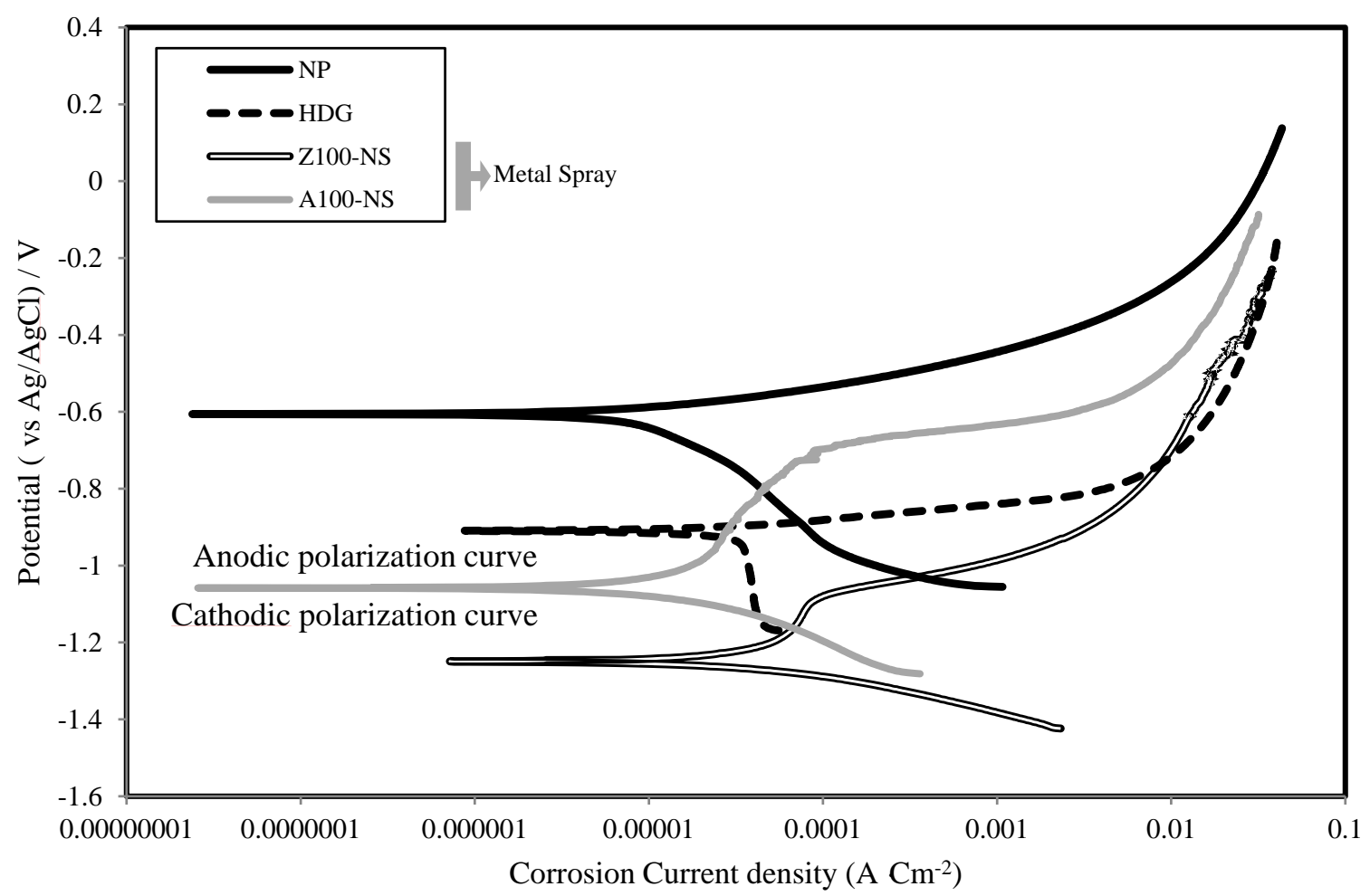

Figure 6 shows the polarization curves of NP, HDG, Z100-NS and Al100-NS specimens. The corrosion potential was about $-1.23 \mathrm{~V}$ in the specimen with the pseudo-alloy of $\mathrm{Zn}-\mathrm{Al}$. In the anodic and cathodic polarization areas, the melting of $\mathrm{Zn}$ occurred easily with a steady increase of the corrosion current density. The corrosion potential of the $\mathrm{Zn}-\mathrm{Sn}$ alloy specimen had a minimum of $-1.30 \mathrm{~V}$, and the corrosion current density was stabilized at $0.0001 \mathrm{~A} \cdot \mathrm{cm}^{-2}$ in the anodic area. Following the melting of $\mathrm{Sn}$ with high solubility, the rapid dissolution of $\mathrm{Zn}$ occurred. Hence, corrosion occurred on the steel surface. On the other hand, the Al-Mg alloy specimen showed a $-1.07 \mathrm{~V}$ corrosion potential. The corrosion current potential was stabilized at $0.000001 \mathrm{~A} \cdot \mathrm{cm}^{-2}$ in the anodic polarization area. This is because aluminum hydroxide coating was formed after the dissolution of $\mathrm{Mg}$. 
Figure 6. Polarization curves of NP, Zn-Al, Zn-Sn and Al-Mg specimens.

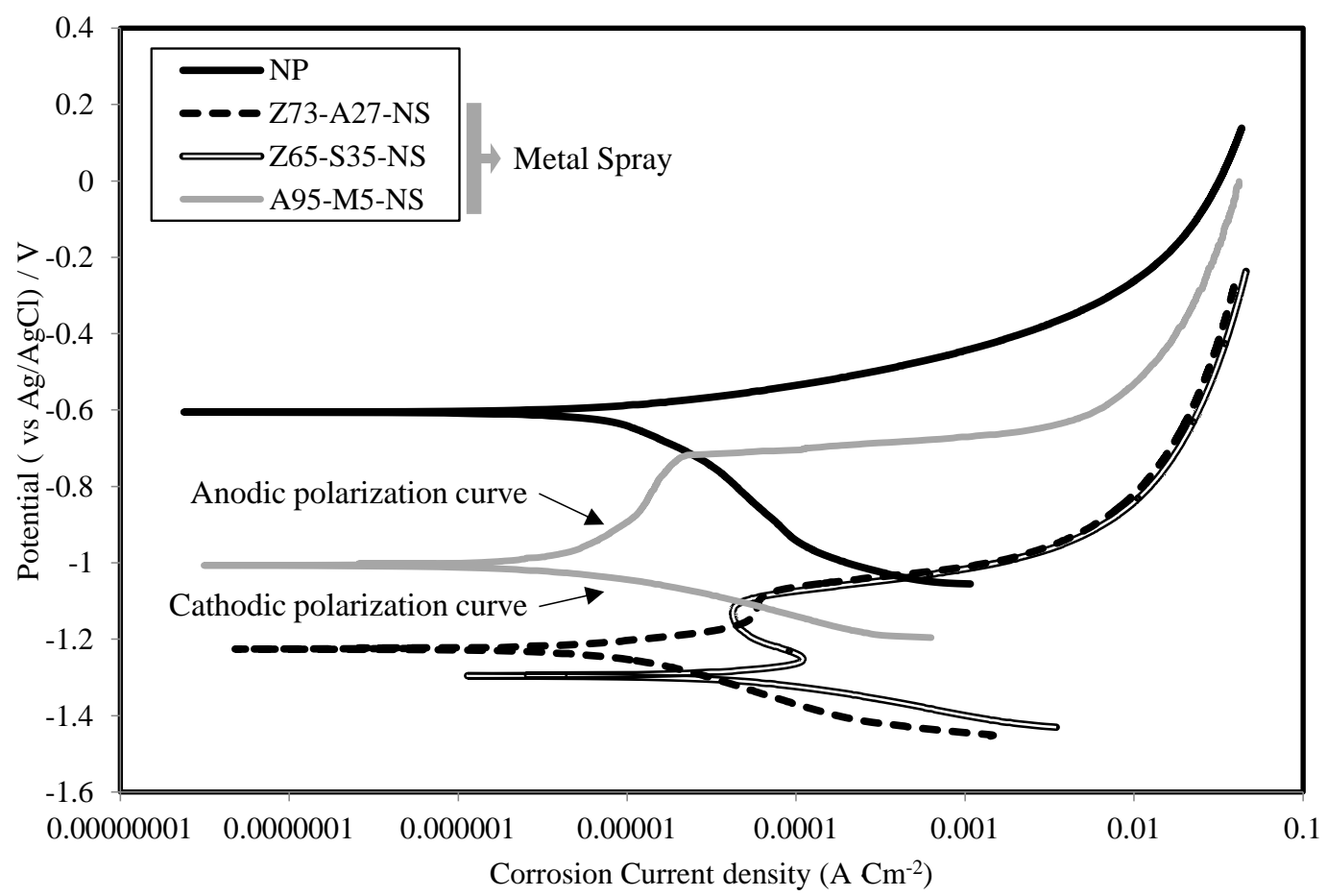

Figure 7 shows the polarization curve of $\mathrm{Zn}-\mathrm{Al}$ and $\mathrm{Al}-\mathrm{Mg}$ specimens without and with epoxy sealing coating. The corrosion potential of the Z73-A27-NS specimen, which was not coated with epoxy sealing coating, is $-1.23 \mathrm{~V}$. This is higher than that of the corrosion potential of the Z73-A27-S specimen of $-0.970 \mathrm{~V}$, in which epoxy sealing coating was applied.

Figure 7. Polarization curves of Z73-A27 with and without epoxy sealing coating.

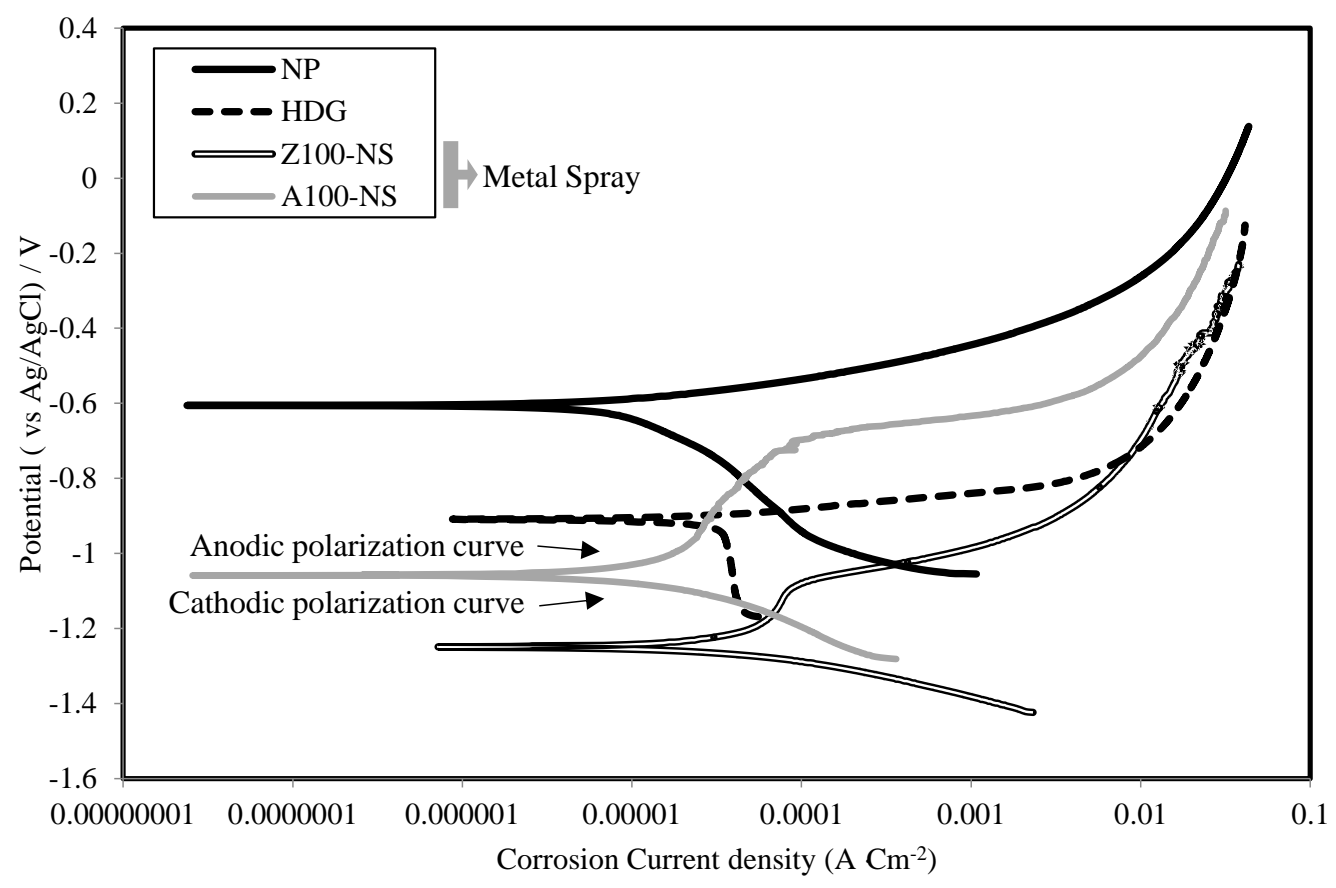


The reason for this may be due to the fact that the epoxy sealing coating obstructs the dissolution of $\mathrm{Zn}-\mathrm{Al}$. The corrosion current density stabilization at about $1.0 \times 10^{-5} \mathrm{~A} \cdot \mathrm{cm}^{-2}$ verifies that there was an obstruction from the epoxy sealing coating, and this is clear from the cathodic polarization area of the specimen with epoxy sealing coating.

A similar observation can be seen in the case of $\mathrm{Al}-\mathrm{Mg}$, and the effect of epoxy sealing coating in this case is significant and makes it obvious that this combination of $\mathrm{Al}-\mathrm{Mg}$ gives the best results in comparison with the other metals used so far.

\subsection{Corrosion Current Density and Polarization Resistance}

The potentiodynamic polarization curve, known as a Tafel plot, depicts the relationship between potential and corrosion current density. This plot exhibits a linear region, the slope of which is known as the Tafel constants (anodic and cathodic Tafel constants). The intersection of the projection of the linear region of the plot with the open circuit potential $\left(E_{\text {corr }}\right)$ gives the cathodic or anodic corrosion current ( $\left.i_{\text {corr }}\right)$. Once $i_{\text {corr }}$ is determined, the following equation, derived from Faraday's law, can be used to calculate the corrosion rate [22]:

$$
\text { Corrosion rate }(\mu \mathrm{m} / \mathrm{y})=\frac{3.27 \times I_{\text {corr }} \times E . W}{d}
$$

The corrosion rate in Equation (1) is expressed in micrometers per year, $\mu \mathrm{m} / \mathrm{y} . I_{\text {corr }}$ is the corrosion current density in $\mu \mathrm{A} \cdot \mathrm{cm}^{-2}$, obtained by dividing $i_{\text {corr }}$ with the exposed surface area of the measured specimen. $E . W$. is the equivalent weight of steel in $\mathrm{g}$, and $d$ is the density of steel in $\mathrm{g} / \mathrm{cm}^{3}$.

The polarization resistance $R_{\mathrm{p}}(\Delta E / \Delta I)$, which is the slope of the potential-current curve at $E_{\text {corr, }}$ is related to $I_{\text {corr }}$ through the following Stern-Geary relationship [23]:

$$
I_{\text {corr }}\left(\mu \mathrm{A} / \mathrm{cm}^{2}\right)=\frac{\left[\beta_{\mathrm{a}} \times \beta_{\mathrm{c}}\right]}{2.3\left(\beta_{\mathrm{a}}+\beta_{\mathrm{c}}\right)} R_{\mathrm{p}}
$$

$\beta_{\mathrm{a}}$ and $\beta_{\mathrm{c}}$ are the anodic and the cathodic Tafel constants, respectively, expressed in $\mathrm{mV} / \mathrm{decade}$ of the current. $R_{\mathrm{p}}$ is expressed in $\mathrm{K} \Omega \cdot \mathrm{cm}^{2}$. It is seen here that for the determination of $I_{\text {corr }}$ in this technique, $\beta_{\mathrm{a}}$ and $\beta_{\mathrm{c}}$ are determined from the Tafel plot.

Table 5 shows the corrosion current density $\left(I_{\text {corr }}\right)$, corrosion rate $(\mathrm{CR})$ and polarization resistance $\left(R_{\mathrm{p}}\right)$ values of each specimen's type. The polarization resistance of specimen Z73-A127-S, with the application of the epoxy sealing coating, was $11.45 \mathrm{~K} \Omega \cdot \mathrm{cm}^{2}$, which is about four-times that of specimen Z73-A127-NS $\left(2.63 \mathrm{~K} \Omega \cdot \mathrm{cm}^{2}\right)$ without the application of the epoxy sealing coating. Thus, the effect of corrosion resistance by the epoxy sealing coating is clear. One can also see that the polarization resistance of specimen A95-M5-S, with the application of the epoxy sealing coating, was $5,255.64 \mathrm{~K} \Omega \cdot \mathrm{cm}^{2}$, which is almost 650 -times that of the same specimen without epoxy sealing coating. Similar outcomes can be seen from the corrosion rate and corrosion current density results. These results confirm that specimen $\mathrm{Al}: \mathrm{Mg}$ (95\%:5\%) produces the best anti-corrosion performance in this present study. 
Table 5. Values of corrosion current density, corrosion rate and polarization resistance of each type of specimen.

\begin{tabular}{ccccc}
\hline No. & $\begin{array}{c}\text { Specimen } \\
\text { Name }\end{array}$ & $\begin{array}{c}\text { Corrosion Current Density } \\
\left(\boldsymbol{\mu} \mathbf{A} \cdot \mathbf{c m}^{-\mathbf{2}}\right)\end{array}$ & $\begin{array}{c}\text { Corrosion Rate } \\
(\boldsymbol{\mu \mathbf { m }} / \mathbf{y})\end{array}$ & $\begin{array}{c}\text { Polarization Resistance } \\
\left(\mathbf{K} \boldsymbol{\Omega} \cdot \mathbf{c m}^{\mathbf{2}}\right)\end{array}$ \\
\hline 1 & NP & 11.30 & 132.48 & 2.30 \\
2 & HDG & 29.10 & 439.18 & 0.50 \\
3 & Z100-NS & 65.90 & 996.33 & 0.35 \\
4 & Z100-S & 28.4 & 429.02 & 0.74 \\
5 & A100-NS & 13.60 & 149.87 & 2.46 \\
6 & A100-S & 0.2 & 2.26 & 521.43 \\
7 & Z73-A27-NS & 7.91 & 111.49 & 2.63 \\
8 & Z73-A27-S & 0.63 & 8.85 & 11.45 \\
9 & Z65-S35-NS & 17.80 & 289.82 & 1.07 \\
10 & Z65-S35-S & 4.28 & 69.81 & 3.07 \\
11 & A95-M5-NS & 7.02 & 79.54 & 28.09 \\
12 & A95-M5-S & 0.02 & 0.29 & $5,255.64$ \\
\hline
\end{tabular}

\section{Conclusions}

Based on the results of this study, the following conclusions may be drawn:

1. The sacrificial anode principle in ATMSM was verified using an electrochemical technique. This is evident from the low values of corrosion current density ( $\left.I_{\text {corr }}\right)$ and high values of polarization resistance $\left(R_{\mathrm{p}}\right)$ of specimens with sprayed metal, such as $\mathrm{Zn}, \mathrm{Al}, \mathrm{Zn}-\mathrm{Al}, \mathrm{Zn}-\mathrm{Sn}$ and $\mathrm{Al}-\mathrm{Mg}$, compared with Fe alone.

2. It is obvious that the corrosion resistance layer generated by applying ATMSM provided a sufficient corrosion resistance with the driving force based on the potential difference of more than approximately $0.60 \mathrm{~V}$ between the layer and the base material.

3. The corrosion potential difference of the specimens in regards to the presence or absence of epoxy sealing coating in the specimens of $\mathrm{Zn}-\mathrm{Al}$ metal thermal spraying is about $0.25 \mathrm{~V}$, while in the case of $\mathrm{Al}-\mathrm{Mg}$, it is $0.16 \mathrm{~V}$. Thus, the effect of the corrosion resistance of steel by epoxy sealing coating suppresses the dissolution of metals, decreases the corrosion current density and increases the polarization resistance.

4. The results of the metal thermal spraying without applying the epoxy sealing coating show that the corrosion current density of the specimen using $\mathrm{Al}-\mathrm{Mg}(95: 5)$ is $7.02 \mu \mathrm{A} \cdot \mathrm{cm}^{-2}$; the corrosion rate is $79.54 \mu \mathrm{m} / \mathrm{y}$; and polarization resistance is $28.09 \mathrm{~K} \Omega \cdot \mathrm{cm}^{2}$. These values in the case of applying the epoxy sealing coating are $0.02 \mu \mathrm{A} \cdot \mathrm{cm}^{-2}, 0.29 \mu \mathrm{m} / \mathrm{y}$ and $5255.64 \mathrm{~K} \Omega \cdot \mathrm{cm}^{2}$, respectively. This is clear evidence that this type of metal thermal spraying has the best performance and exceeds even the $\mathrm{Zn}-\mathrm{Al}$ type.

\section{Acknowledgments}

This research was supported by a grant (12-Advanced City-D02:13CHUD-C063720-02) from Construction Technology Research Program (CTRP) funded by the Ministry of Land, Infrastructure and Transport (MLIT), Government of the Republic of Korea. 


\section{Author Contributions}

Hong-Bok Choe conducted the experiments and wrote the initial draft of the manuscript. Han-Seung Lee designed the project and analyzed the data. Jun-Ho Shin wrote the final manuscript. All authors contributed to the analysis of the data and read the final paper.

\section{Conflicts of Interest}

The authors declare no conflict of interest.

\section{References}

1. Cocco, V.D.; Iacoviello, F.; Natali, S. Damaging micromechanisms in hot-dip galvanizing $\mathrm{Zn}$ based coatings. Theor. Appl. Fract. Mech. 2014, 70, 91-98.

2. Nishimura, T.; Raman, V. Corrosion prevention of aluminum nanoparticles by a polyurethane coating. Materials 2014, 7, 4710-4722.

3. Martinez, S.; Žulj, L.V.; Kapor, F. Disbonding of underwater-cured epoxy coating caused by cathodic protection current. Corros. Sci. 2009, 51, 2253-2258.

4. Dong, S.G.; Zhao, B.; Lin, C.J.; Du, R.G.; Hu, R.G.; Zhang, G.X. Corrosion behavior of epoxy/zinc duplex coated rebar embedded in concrete in ocean environment. Constr. Build. Mater. 2012, 28, 72-78.

5. Kim, T.S.; Lee, H.S.; Yoo, J.H.; Tae, S.H.; Oh, S.H.; Lim, Y.C.; Lee, S.B. Slip coefficient in high-strength bolt joints coated with corrosion-resistant $\mathrm{Zn} / \mathrm{Al}$ metal spray method. Mater. Manuf. Proc. 2011, 26, 14-21.

6. Guideline of Design and Construction of Melted Zinc Coated Bridge; JSSC (Japanese Society of Steel Construction): Tokyo, Japan, 1997; pp. 57-60.

7. Guenbour, A.; Benbachir, A.; Kacemi, A. Evaluation of the corrosion performance of zinc-phosphate-painted carbon steel. Surf. Coat. Technol. 1999, 113, 36-43.

8. Cinca, N.; Lima, C.R.C.; Guilemany, J.M. An overview of intermetallics research and application: status of thermal spray coatings. J. Mater. Res. Technol. 2013, 2, 75-86.

9. Bettridge, D.F.; Ubank, R.G. Quality control of high-temperature protective coatings. Mater. Sci. Technol. 1986, 2, 232-242.

10. Seré, P.R.; Zapponi, M.; Elsner, C.I.; Di Sarli, A.R. Comparative corrosion behaviour of 55 aluminium-zinc alloy and zinc hot-dip coatings deposited on low carbon steel substrates. Corros. Sci. 1998, 40, 1711-1723.

11. Sá Brito, V.R.S.; Bastos, I.N.; Costa, H.R.M. Corrosion resistance and characterization of metallic coatings deposited by thermal spray on carbon steel. Mater. Des. 2012, 41, 282-288.

12. Kang, C.; Lee, H.; Tae, S.; Cho, Y.; Jang, H.; Lee, S. A prediction of the anti-corrosion life in a steel applying $\mathrm{Zn}-\mathrm{Al}$ thermal metal spraying method using an electrochemical experiment. Mater. Manuf. Proc. 2011, 26, 22-28.

13. Itoh, Y.; Shimizu, Y.; Koyama, A. Durability of steel bridge metallic coating system for combined cyclic corrosion tests with salt water spray and acid rain spray. J. JSCE A 2007, 63, 795-810. 
14. Liu, A. Electrochemical performance and corrosion resistance of $\mathrm{Zn}-\mathrm{Al}$ pseudo-alloy coatings in chlorine ion-containing environment. J. Univ. Sci. Technol. B. 2012, 34, 1054-1060.

15. Campo, M.; Carboneras, M.; López, M.D.; Torres, B.; Rodrigo, P.; Otero, E.; Rams, J. Corrosion resistance of thermally sprayed $\mathrm{Al}$ and $\mathrm{Al} / \mathrm{SiC}$ coatings on Mg. Surf. Coat Technol. 2009, 203, 3224-3230.

16. Jiang, Q.; Miao, Q.; Liang, W.P.; Ying, F.; Tong, F.; Xu, Y.; Ren, B.L.; Yao, Z.J.; Zhang, P.Z. Corrosion behavior of arc sprayed $\mathrm{Al}-\mathrm{Zn}-\mathrm{Si}-\mathrm{RE}$ coatings on mild steel in $3.5 \mathrm{wt} \% \mathrm{NaCl}$ solution. Electrochim. Acta 2014, 115, 644-656.

17. De Rincón, O.; Rincón, A.; Sánchez, M.; Romero, N.; Salas, O.; Delgado, R.; López, B.; Uruchurtu, J.; Marroco, M.; Panosian, Z. Evaluating Zn, Al and Al-Zn coatings on carbon steel in a special atmosphere. Constr. Build. Mater. 2009, 23, 1465-1471.

18. Kuroda, S.; Kawakita, J.; Takemoto, M. An 18-year exposure test of thermal-sprayed Zn, Al, and $\mathrm{Zn}-\mathrm{Al}$ coatings in marine environment. Corrosion 2006, 62, 635-647.

19. Jiang, Q.; Miao, Q.; Tong, F.; Xu, Y.; Ren, B.L.; Liu, Z.M.; Yao, Z.J. Electrochemical corrosion behavior of arc sprayed Al-Zn-Si-RE coatings on mild steel in $3.5 \% \mathrm{NaCl}$ solution. Trans. Nonferr. Met. Soc. China 2014, 24, 2713-2722.

20. Xiao, Y.; Jiang, X.; Xiao, Y.; Ma, L. Research on Zn-Al15 thermal spray metal coating and its organic painting composite system protection performance. Procedia Eng. 2012, 27, 1644-1653.

21. Asgari, H.; Toroghinejad, M.R.; Golozar, M.A. Effect of coating thickness on modifying the texture and corrosion performance of hot-dip galvanized coatings. Curr. Appl. Phys. 2009, 9, 59-66.

22. Dean, S.W. Electrochemical methods of corrosion testing. In Electrochemical Techniques for Corrosion; Baboian, R., Ed.; NACE: Houston, TX, USA, 1977; pp. 52-60.

23. Stern, M.; Geary, A.L. Electrochemical polarization, No. 1 theoretical analysis of the shape of polarization curves. J. Electrochem. Soc. 1957, 104, 56-57.

(C) 2014 by the authors; licensee MDPI, Basel, Switzerland. This article is an open access article distributed under the terms and conditions of the Creative Commons Attribution license (http://creativecommons.org/licenses/by/4.0/). 